\title{
A natureza (dos) nos fatos urbanos: produção do espaço e degradação ambiental
}

\section{The nature (of) our urban facts: productions of space and environmental degradation}

\author{
Gislene PEREIRA* \\ Desculpa se tudo isso é uma coisa óbvia; mas para muitos, que tu conheces, \\ ainda não é; mostra-lhes, pois, estas linhas. \\ Mario Quintana \\ Suplicamos expressamente: não aceiteis o que é de hábito como coisa natural. \\ Bertold Brecht
}

\begin{abstract}
RESUMO
Este trabalho pretende discutir a relação entre o processo de construção do espaço urbano, a segregação socioespacial e a degradação ambiental. A urbanização crescente da população no Brasil tem feito com que os problemas decorrentes desse processo (carência de infra-estrutura, densificação de áreas inadequadas, degradação ambiental, segregação socioespacial) centralizem nas últimas décadas as discussões de governantes, técnicos e cientistas sociais. Cabe, então, perguntar: por que nossas cidades não têm a qualidade que todos queremos, mesmo depois das inúmeras iniciativas preconizadas pelo poder público para reversão dessas tendências negativas? Nosso interesse aqui é discutir essas questões a partir do caso particular da cidade de Curitiba, a qual, apesar de vir se destacando por experiências bem sucedidas de planejamento, segue os padrões brasileiros no que se refere à segregação socioespacial. Entendemos que a discussão das questões urbanas deve ser centrada nos elementos que contribuem para a segregação socioespacial e nas possibilidades e limites das políticas públicas de controle do uso do solo respondendo de forma positiva para a sua superação. A partir do conhecimento da lógica da produção do espaço o trabalho pretende averiguar as possibilidades de integração das políticas urbanas, com o objetivo de promover a melhoria da qualidade ambiental.
\end{abstract}

Palavras-chave: estruturação urbana, segregação socioespacial, políticas urbanas

\footnotetext{
* Professora do Departamento de Arquitetura e Urbanismo da UFPR, Mestre em Planejamento Urbano e Regional - IPPUR/UFRJ, Doutoranda em Meio Ambiente e Desenvolvimento - MAD/UFPR. E-mail: gislene@ arquit.ufpr.br
} 


\begin{abstract}
This work intends to discuss the relation among the process of construction of the urban space, the social-spacial segregation and the environmental degradation. The growing urbanisation of the Brazilian population has led the problems which come from such process - lack of infrastructure, unsuitable densification of areas, environmental degradation, social-space segregation - to centralize the discussion of governmental rulings, technicians and social scientists. So, it's worthy to ask: why our cities do not have the quality we want, even after several initiatives advocated by the public policies to revert these negative trends? Our interest here is to discuss such questions from the particular case of Curitiba city, the one which, despite of being standing out itself throughout well-succeded experiences of planning, follows the Brazilian patterns related to the social-spacial segregation. We understand that the discussion of urban questions must be focused on the elements which contribute to the social-spacial segregation and on the possibilities and limits of the public policies to answer in a positive way to their overcoming. From the knowledge of the production logic of the space, this work intends to check out the possibilities of integration of the urban policies, with the aim of promoting the increasing of the environmental quality.
\end{abstract}

Key-words: urban structure, social-spacial segregation, urban policies

Este trabalho tem como ponto de partida indagações sobre a relação entre espaço, economia e sociedade no processo de degradação ambiental urbana. As questões que orientam a discussão aqui apresentada são: por que nossas cidades não têm a qualidade que queremos, se temos à disposição conhecimento teórico e prático sobre o urbano bem como tecnologias avançadas? Por que se fala em "crise" da cidade, se o conceito de crise diz respeito a um fenômeno que ocorre em um determinado período de tempo, e, no entanto, a crise urbana tem sido permanente, crescendo junto com as cidades?

O baixo padrão de qualidade ambiental dominante nas cidades brasileiras indica que essas questões não são tão óbvias quanto inicialmente parecem. O que, sim, é óbvio, é a necessidade de discutir os elementos da problemática ambiental urbana. Esta é a proposta deste texto: um exercício reflexivo sobre a questão ambiental na cidade, de forma a subsidiar propostas de melhoria da qualidade de vida urbana.

\section{A produção social do ambiente urbano e das de- sigualdades}

Partimos do conceito de "meio ambiente urbano", definido por Rodrigues como "conjunto das edificações, com suas características construtivas, sua história e memória, seus espaços segregados, a infra-estrutura e os equipamentos de consumo coletivo."1

Conforme a autora, o conceito de meio ambiente urbano refere-se ao ambiente construído, uma vez que o ambiente natural está desaparecendo das cidades, sobrepujado pelas formas concretas de ocupação do território (rios canalizados, vegetação derrubada, solo impermeabilizado, entre outras). Ao referir-se ao conjunto de atividades exercidas na cidade, o conceito de ambiente urbano compreende, portanto, a dinâmica da própria sociedade. ${ }^{2}$

O homem, para sobreviver, necessita ocupar um lugar no espaço e essa ocupação envolve o ato de produzir o 
lugar. A produção do espaço é ação cotidiana do homem e aparece na forma de ocupação de um determinado lugar em um momento histórico. ${ }^{3}$ Os problemas ambientais dizem respeito, portanto, às formas pelas quais o homem produz esse lugar com o objetivo de garantir suas condições de sobrevivência.

A compreensão do espaço como uma produção social leva à compreensão de que a questão ambiental decorre das relações entre os homens e não apenas das relações entre homem e natureza. Como coloca Rodrigues, a questão ambiental refere-se não apenas aos "problemas da natureza, meio físico, mas também, e sobretudo, à problemática decorrente da ação societária."4

Tomamos como referência a hipótese apresentada por Lefebvre $^{5}$ da urbanização completa da humanidade, hoje, ainda virtual, mas proximamente real. Nessas condições, o autor propõe como categoria de análise científica a expressão sociedade urbana. Esta categoria responderia a uma necessidade teórica para compreensão da realidade, marcada pelo que o autor denominou "revolução urbana": conjunto de transformações que se produzem na sociedade contemporânea para marcar a passagem do período no qual predominam os problemas de crescimento e da industrialização para aquele no qual predominará a problemática urbana e onde a busca de soluções e modelos próprios à sociedade urbana estará em primeiro plano.

A aceitação da hipótese que a sociedade é (ou tende a ser) urbana, a tal ponto de ser essa expressão uma categoria científica, implica em reconhecer que quando nos referimos ao espaço que o homem precisa para sobreviver estamos nos referindo ao espaço urbano e quando falamos da produção do espaço, estamos falando de produção do espaço urbano.

Por outro lado, não tratamos de um espaço abstrato, mas da cidade que é fruto do processo de desenvolvimento capitalista que, em essência, é desigual e demonstra essa desigualdade na contraposição entre "ilhas" de riqueza, e áreas urbanas miseráveis, desprovidas de qualquer benefício.

Ao produzir o espaço urbano a sociedade se apropria da natureza e a transforma, criando mercadorias desejáveis e indesejáveis. As mercadorias desejáveis fazem parte do ideário do desenvolvimento: objetos, serviços, equipamentos, que vão desde automóveis e casas até serviços telefônicos e de infra-estrutura. As mercadorias indesejáveis são aquelas que não foram planejadas como mercadorias, são consideradas desvios do modelo de desenvolvimento: alimentos deteriorados, automóveis poluidores e também subhabitações, "lixões". Os produtos pensados para o desenvolvimento, ao se transformarem em problemas, demonstram as contradições do processo de produção.

A compreensão da questão ambiental passa, portanto, pela compreensão da complexidade do processo de apropriação, produção e consumo do espaço, que é um processo "no qual se produzem e/ou reproduzem relações sócioespaciais e se reproduzem relações dominantes de produção e de reprodução como parte integrante das relações societárias com a natureza."

Apesar da cidade ser o produto da forma de apropriação da natureza pela sociedade, quando se trata de analisar o padrão de urbanização, em geral, a natureza está oculta. Conforme indicado por Smith, citado por Rodrigues: ${ }^{7}$

...a natureza geralmente é vista como aquilo que não pode ser produzido; é a antítese da atividade produtiva humana. Em uma aparência mais imediata, a paisagem natural apresenta-se a nós como o substratum material da vida diária, (...) quando essa aparência imediata da natureza é colocada no contexto histórico, o desenvolvimento da paisagem material apresenta-se como um processo de produção da natureza.

[E o autor afirma:] a menos que o espaço seja conceituado como realidade completamente separada da natureza, a produção do espaço é um resultado lógico da produção da natureza. ${ }^{8}$

Rodrigues reforça essa afirmação ao colocar que "a cidade é uma das obras do homem que, apropriando-se da natureza, a transforma de tal maneira que a faz 'simbolicamente' desaparecer como tal." 9

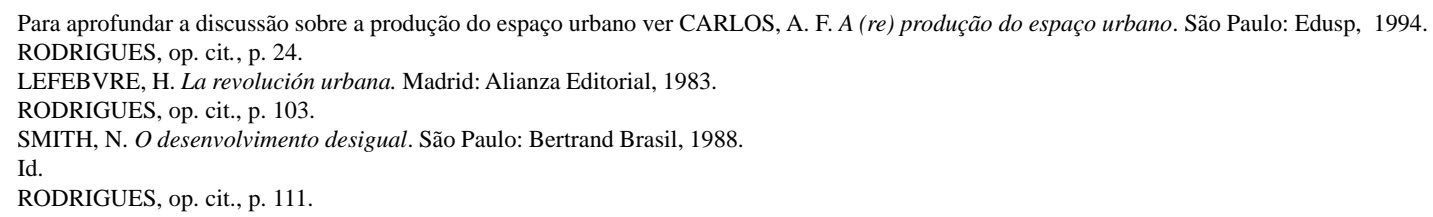


A autora coloca que os diagnósticos das condições de vida urbana - denominados de indicadores de qualidade de vida - consideram apenas as mercadorias "desejáveis" produzidas pela sociedade, sendo que as indesejáveis não são reconhecidas como também resultantes dessa produção da cidade. Como exemplo, a autora cita o conjunto de indicadores de saneamento básico, no qual estão incluídos a rede de água potável, esgotamento sanitário, coleta e disposição do lixo. A autora chama a atenção para a contradição desse indicador uma vez que o acesso à água potável (recurso natural) só é um indicador de qualidade porque a água limpa é escassa e nem todos têm acesso a ela. A poluição da água não é identificada, portanto, como mercadoria indesejável, resultante do processo de produção do espaço, mas, sim como desvio desse processo, que tem por meta a melhoria da qualidade de vida na cidade. Dessa maneira, uma medida dessa qualidade - abastecimento de água potável - contém em si sua própria negação, pois quanto maior o "progresso" urbano (aumento populacional, industrial etc.) mais escasso, raro e caro será o recurso natural - água.

Não se pode pensar em soluções para a problemática ambiental urbana sem considerá-la como inserida em um processo produtivo de mercadorias, no qual as mercadorias consideradas desejáveis são produzidas simultaneamente às indesejáveis. Como coloca Rodrigues:

Não é possível realizar diagnósticos das diferentes causas que provocam desigualdades e o não acesso à urbanidade e propor que se implemente "saneamento" como a melhora destas condições se não forem compreendidos seus aspectos contraditórios. Não é possível conceber que a contradição seja resolvida com a aceleração apenas da implementação de mercadorias, que são fruto e semente do que se critica. ${ }^{10}$

\section{A produção da segregação social do espaço}

A questão da produção do espaço urbano tem sido objeto de numerosos estudos. Baseamo-nos aqui nos trabalhos de Lefebvre, ${ }^{11}$ Harvey, ${ }^{12}$ Castells ${ }^{13} \mathrm{e}$ Gottdiener, ${ }^{14}$ que enfocam a produção da cidade como manifestação espacial dos conflitos de interesses dos diversos agentes presentes nesse processo, associado ao desenvolvimento capitalista.

O mecanismo essencial de produção da cidade capitalista baseia-se no princípio econômico da busca do máximo benefício, segundo o qual o solo, bem escasso e de uso necessário para todos, é convertido em valor de troca, ao aplicar-se capital e trabalho mediante a urbanização e a construção. Os elementos da cidade (solo, edifícios, habitações) convertem-se em mercadoria, comercializada como qualquer outra, com preços fixados pela lei da oferta e demanda. Desta maneira, a propriedade privada, fundamento do modo de produção capitalista, se beneficia do valor de troca e se apropria dos valores que a coletividade cria na cidade através da urbanização. As contínuas transformações da paisagem urbana também são consequiência da busca do máximo benefício pelo capital.

A propriedade privada do solo urbano, por si só, proporciona renda para quem a detém e, por isso, é assemelhada ao capital. Ou seja, o solo urbano tem a capacidade de gerar renda, reproduzindo seu valor e mais um valor excedente, que aparece para o proprietário sob a forma de lucro. A propriedade imobiliária é, portanto, um "capital" imobiliário. Entretanto, como coloca Singer, o capital imobiliário é um "falso capital", na medida em que, apesar de ele se valorizar, a origem de sua valorização não é a atividade produtiva, mas o monopólio do acesso a uma condi-

10 RODRIGUES, op. cit., p. 116.

11 O autor discute a associação entre fatores políticos, culturais e econômicos na dinâmica de estruturação da cidade. Para Lefebvre, a transformação da sociedade moderna em sociedade humanista deve ocorrer na forma de uma "revolução .urbana" - uma revolução em torno da vida cotidiana desalienada, além da transformação econômica exigida pelos marxistas. Ver LEFEBVRE, H. La revolución urbana. Madri: Alianza, 1983; LEFEBVRE, H. The production of space. Massachusetts: Blackwell, 2000 .

12 Em sua obra o autor questiona a natureza da teoria, a natureza do espaço, a natureza da justiça social e a natureza do urbanismo. Especificamente em relação ao urbanismo, o autor considera este como uma série de relações sociais que refletem as relações estabelecidas por toda a sociedade. Ver HARVEY, D. A justiça social e a cidade. São Paulo: Hucitec, 1980; HARVEY, D. A condição pós-moderna. Rio de Janeiro: Paz e Terra, 1999.

13 Castells considera a cidade como um produto ao mesmo tempo do Estado e da economia, enfocando os processos sociais urbanos sob a ótica da inter-relação entre os serviços sociais que o Estado provê e a reprodução da força de trabalho. Ver CASTELLS, M. A questão urbana. Rio de Janeiro: Paz e Terra, 1983; CASTELLS, M. A sociedade em rede. Rio de Janeiro: Paz e Terra, 1999.

$14 \mathrm{O}$ autor aponta para a necessidade da compreensão das forças que moldam o espaço, especialmente o uso deste pelo Estado e pela economia. Este seria o caminho para se explicar as diferentes formas que assume o ambiente construído. Ver GOTTDIENER, M. A produção social do espaço urbano. São Paulo: Edusp, 1997. 
ção indispensável àquela atividade. ${ }^{15} \mathrm{O}$ solo assume um valor por ser necessário à produção capitalista, como espaço onde a atividade humana se realiza, e estar sob o monopólio do proprietário.

Carlos chama a atenção para o fato de que a cidade é expressão, ao mesmo tempo, de um processo de produção e de uma forma de apropriação do espaço produzido. Como parte de um processo de produção ela é condição e meio para que se instituam relações sociais diversas, essas relações, por sua vez, se materializam nas diversas formas de apropriação do espaço urbano, ou seja, nos padrões de uso do solo urbano. Como coloca Carlos:

O uso do solo ligado a momentos particulares do processo de produção das relações capitalistas é o modo de ocupação de determinado lugar da cidade, a partir da necessidade de realização de determinada ação, seja a de produzir, consumir, habitar ou viver. O ser humano, necessita, para viver, ocupar um determinado lugar no espaço. Só que o ato em si não é meramente o de ocupar uma parcela do espaço; ele envolve o ato de produzir o lugar. ${ }^{16}$

A produção do espaço urbano se realiza no cotidiano da população e se expressa pela forma de ocupação ou utilização de determinado lugar em um momento específico. De acordo com Carlos:

O uso do solo urbano é disputado pelos vários segmentos da sociedade de forma diferenciada, gerando conflitos entre indivíduos e usos. Esse pleito será, por sua vez, orientado pelo mercado, mediador fundamental das relações que se estabelecem na sociedade capitalista, produzindo um conjunto limitado de escolhas e condições de vida. Portanto, a localização de uma atividade só poderá ser entendida no contexto do espaço urbano como um todo, na articulação da situação relativa dos lugares. Tal articulação se expressará na desigualdade e heterogeneidade da paisagem urbana. ${ }^{17,18,19}$

Confirmando que o solo urbano constitui elemento fundamental na produção capitalista da cidade Queiroz Ribeiro coloca que, para esta produção, o solo é "um suporte físico sobre o qual o capital se metamorfoseia em mercadorias, em bens imóveis; e, para o consumo habitacional, ele representa um espaço vital de reprodução."20

Rolnik também se remete à importância do solo urbano na estruturação das cidades, ao afirmar que:

O mercado de terras (solo urbano) determina a forma de estruturação da cidade, em conjunto com a política de investimentos urbanos, as políticas de investimento em infra-estrutura e com a relação que ele estabelece com as estratégias de regulação urbana - ou seja, com a Legislação urbana, com a Legislação ambiental, e com tudo aquilo que venha interferir no funcionamento desse mercado. $^{21}$

Para ocupar o solo urbano é necessário pagar por ele, mediante a compra ou aluguel da propriedade imobiliária. O mercado é o elo entre as relações sociais de produção e o uso da cidade, determinando a possibilidade de uso e ocupação do solo mediante o pagamento do preço por ele estipulado.

O preço desse imóvel é expressão do seu valor. Mas que valor é esse? Qual é o valor do espaço urbano? Segundo Villaça ${ }^{22}$ existem dois valores a serem considerados

15 SINGER, P. O uso do solo na economia capitalista. In: MARICATO, E. (Org.). A produção capitalista da casa (e da cidade). São Paulo: Alfa-Omega, 1979. 16 CARLOS, A. F. A. A (re) produção do espaço urbano. São Paulo: Edusp, 1994. p. 85.

17 Id.

18 Para GOTTDIENER, op. cit., os conflitos no processo de produção da cidade são gerados pela oposição de interesses associados aos valores de uso e valores de troca do espaço urbano, isto é, há um permanente conflito entre aqueles agentes que buscam incrementar o valor de troca do espaço urbano e os que defendem o valor de uso. Em geral, esses conflitos são tolerados ou assumidos pela estrutura política institucional, que, quando necessário, intervém, em favor de um ou outro grupo, tornando claro seu papel de agente mediador, além de também produtor do espaço urbano.

19 A distinção entre valor de uso e valor de troca tem sido tema de considerações para os economistas políticos desde o século XIX. Tratamos aqui estes conceitos na perspectiva apresentada por Harvey (1980), ou seja, valor de uso estaria associado à utilidade de um bem e valor de troca à potencialidade comercial desse bem. A inter-relação entre o valor de uso e valor de troca da mercadoria solo é considerada por Harvey como a base para uma discussão adequada do uso do solo urbano. 20 QUEIROZ RIBEIRO, L. C. Notas sobre a renda da terra urbana. Cadernos IPPUR/UFRJ, Rio de Janeiro, n.1, p. 46, jan./abr., 1986.

21 ROLNIK, R. Cidades sustentáveis: memória do encontro preparatório. In: Conferência sustentabilidade e gestão urbana,1997, São Paulo. Anais... São Paulo: Secretaria do Meio Ambiente, set. 1997. p. 20.

22 VILLAÇA, F. Espaço intra-urbano no Brasil. São Paulo: Studio Nobel, 1998. 
nesse caso. O primeiro diz respeito ao valor dos elementos formadores do espaço urbano - edifícios, ruas, praças, infraestrutura. $\mathrm{O}$ outro refere-se ao valor produzido pela aglomeração, isto é, o valor decorrente da localização desses elementos dentro dessa aglomeração e que está associado ao valor de toda a cidade, da qual a localização é parte.

Dessa afirmação pode-se concluir que a produção do espaço é, na verdade, a produção de localizações. As diferentes localizações apresentam diferentes valores, associados não somente ao valor dos elementos urbanos aí existentes mas também a maior ou menor acessibilidade aos bens e serviços existentes na cidade. Essa diferenciação entre valores das localizações explica a diferença de valor das áreas urbanas.

Villaça afirma que o valor da localização é irreproduzível, porque

ela é como as obras de arte e antigüidades: fruto do trabalho humano que não pode ser reproduzido pelo trabalho humano (...) É impossível produzir duas esquinas das avenidas São João e Ipiranga, Rio Branco e Presidente Vargas. (...) O espaço urbano é intrinsecamente desigual e essa desigualdade é resultado das diferenças de acessibilidade a todos os pontos do espaço urbano. ${ }^{23}$

Os diferentes valores (traduzidos em preços) assumidos pelas áreas urbanas implicam em uma distribuição espacial da população de acordo com a capacidade desta em arcar com os custos de localizações específicas. Essa é a razão da existência na cidade de áreas onde predominam grupos sociais homogêneos sob o ponto de vista da renda.

As áreas melhor localizadas e, portanto, com maior valor, são ocupadas pela população de maior renda, restando à parcela de menor poder aquisitivo a ocupação das áreas de menor valor, com restrita acessibilidade a bens e serviços urbanos. Tal processo se expressa na segregação social do espaço.

Milton Santos $^{24}$ coloca que, com diferenças de grau e intensidade, todas as cidades brasileiras apresentam problemas parecidos: carência generalizada de habitação, sa- neamento, transportes e demais serviços urbanos. Quanto à estruturação, caracterizam-se pela ocupação de vastas superfícies, entremeadas de vazios, gerando um modelo de ocupação centro-periferia, onde as carências dessa última criam diferenciais no valor da terra central e alimentam a especulação imobiliária. Esta, por sua vez, num verdadeiro círculo vicioso, fortalece o processo de extensão da área urbana, criando novas periferias, e aumentando os problemas. Como coloca o autor, "a organização interna de nossas cidades (...) revela um problema estrutural, cuja análise sistêmica permite verificar como todos os fatores mutuamente se causam, perpetuando a problemática." 25

De acordo com o mesmo autor:

A especulação imobiliária deriva, em última análise, da conjugação de dois movimentos convergentes: a superposição de um sítio social ao sítio natural e a disputa entre atividades e pessoas por dada localização. A especulação se alimenta dessa dinâmica, que inclui expectativas. Criam-se sítios sociais, uma vez que o funcionamento da sociedade urbana transforma seletivamente os lugares, afeiçoando-os às suas exigências funcionais. É assim que certos pontos se tornam mais acessíveis, certas artérias mais atrativas e, também, uns e outros, mais valorizados. Por isso são atividades mais dinâmicas que se instalam nessas áreas privilegiadas: quanto aos lugares de residência, a lógica é a mesma, com as pessoas de maiores recursos buscando alojar-se onde lhes pareça mais conveniente, segundo os cânones de cada época, o que também inclui a moda. É desse modo que as diversas parcelas da cidade ganham ou perdem valor ao longo do tempo. ${ }^{26}$

\section{Propriedade da terra, pobreza urbana e segrega- ção socioespacial}

A questão da ilegalidade da propriedade do solo urbano vem ganhando destaque nas discussões sobre a estruturação das cidades no Brasil. De acordo com Maricato,

23 VILLAÇA, op. cit., p. 355.

24 SANTOS, M. A urbanização brasileira. São Paulo: Hucitec, 1994.

25 Ibid., p. 97.

26 Ibid., p. 96; VILLAÇA, op. cit., p. 141. 
que discute a oposição entre cidade real e cidade legal, "o uso ilegal do solo e a ilegalidade das edificações em meio urbano atingem mais de $50 \%$ das construções nas grandes cidades brasileiras, se considerarmos as legislações de uso e ocupação do solo, zoneamento, parcelamento do solo e edificação."27

Cenecorta e Smolka, em um trabalho que discute as características do mercado de terras na América Latina, defendem que a questão da legalização da propriedade é derivada da questão do acesso à terra servida, isto é, terra destinada ao uso urbano e equipada com infra-estrutura básica, no patamar exigido para os parcelamentos residenciais. Nessas condições, os autores colocam que "uma oferta suficiente de terra servida a preços acessíveis anularia, em princípio, a necessidade da posse ilegal." 28

As razões da ilegalidade decorrem tanto do baixo rendimento de uma grande parcela da população urbana, bem como da reduzida oferta de terras no âmbito do mercado imobiliário formal, uma vez que os empreendedores imobiliários não têm interesse nem incentivos para investir nesse segmento do mercado. Como colocam os autores acima citados, "as explicações para esse fenômeno são encontradas não só na argumentação econômica mas também no ambiente político e cultural criado na maioria dos países latino-americanos desde, a revolução demográfica e urbanizadora iniciada no final dos anos 40." 29

A ilegalidade em relação à propriedade da terra na cidade leva a um processo de exclusão social da população de menor renda, uma vez que à regularidade urbanística está associado o acesso aos demais serviços urbanos, desde a infra-estrutura básica até o exercício dos direitos de cidadania. Como coloca Boaventura Santos, citado em Maricato, referindo-se a um estudo sobre a dimensão jurídico-social de uma favela chamada Pasárgada:

A expressão "nós éramos e somos ilegais" (de um antigo morador da favela), que, no seu contexto semântico, liga o status de ilegalidade com a própria condição humana dos habitantes de Pasárgada, pode ser interpreta- da como indicação de que nas atitudes destes para com o sistema jurídico nacional, tudo se passa como se a legalidade da posse da terra repercutisse sobre todas as outras relações sociais, mesmo sobre aquelas que nada têm com a terra ou com a habitação. ${ }^{30}$

A ilegalidade, ao contribuir para a exclusão social, reforça a pobreza urbana, estabelecendo um ciclo vicioso, demonstrado por Cenecorta e Smolka, ${ }^{31}$ no diagrama abaixo:

\section{$O$ ciclo vicioso da informalidade}

\author{
Urbanização da pobreza \\ $\downarrow$ \\ Necessidades sociais excedendo a base tributária \\ Ausência de recursos públicos para financiar \\ provisão de serviços \\ $\downarrow$ \\ Escassez de terras servidas/urbanizadas \\ $\downarrow$ \\ Supervalorização de terras servidas \\ $\downarrow$ \\ Preços não acessíveis \\ $\downarrow$ \\ Ocupações de terra ilegais/irregulares \\ Custo de vida mais alto \\ $\boldsymbol{v}$ \\ Aumento da pobreza urbana
}

A ilegalidade em relação à posse da terra, além de fator de exclusão social da população de menor renda, é o principal agente do padrão de segregação espacial que caracteriza as cidades brasileiras.

As diversas localizações urbanas, resultantes do processo de produção da cidade, assumem diferentes preços, estabelecidos pelo mercado imobiliário. As áreas melhor

\footnotetext{
27 MARICATO, E. Metrópole na periferia do capitalismo; ilegalidade, desigualdade e violência. São Paulo: Hucitec, 1996. p. 21.

28 CENECORTA, A.; SMOLKA, M. O paradoxo da regularização fundiária: acesso à terra servida e pobreza urbana no México. Cadernos IPPUR. Rio de Janeiro, ano 14 , n. 1, p. 87 , jan./jul. 2000.

30 SANTOS, B. S. Notas sobre a história jurídico social de Pasárgada. In: SOUZA JUNIOR, J. G.(Org.). Introdução crítica ao direito. Brasília: Universidade de Brasília, 1993.

31 CENECORTA; SMOLKA, op. cit., p. 99.
} 
localizadas são mais caras e serão ocupadas pela população que têm renda para arcar com esses custos. A população de menor poder aquisitivo tende a ocupar áreas desvalorizadas no mercado imobiliário, como a periferia urbana, precária de serviços, e regiões ambientalmente frágeis fundos de vale, encostas, áreas sujeitas à inundações, áreas de proteção ambiental.

\section{Segregação social e degradação ambiental}

A relação entre pobreza e degradação do ambiente particulariza a discussão sobre os problemas ambientais nas cidades brasileiras. Como coloca Herculano,

a pobreza e a deterioração ambiental formam um círculo vicioso, no qual cada termo é causa do outro. ${ }^{32}$

E, continuando a afirmação, a mesma autora coloca que pobreza e degradação ambiental não são percebidas (...) enquanto inerentes à lógica perversa de um modo de produção concentrador, mas como percalços inesperados e perversos, passíveis de serem contornados e controlados através de ajustes e correções. ${ }^{33}$

As características do espaço produzido dentro da lógica capitalista refletem as desigualdades geradas por essa lógica. Num processo de produção do espaço que se baseia na maximização do lucro que o solo pode gerar e na exigência de uma renda mínima para ter acesso a esse solo, a exclusão social é estrutural. A população de maior renda tende a beneficiar-se do processo de produção da cidade e os mais pobres permanecem à margem, por não disporem de recursos financeiros que permitam sua inserção nesse processo.

A segregação social gerada pela cidade capitalista é expressão do sistema econômico que a sustenta e essa situação, como coloca Mueller, "criou um tipo especial de degradação ambiental de difícil erradicação - aquela que resulta da provisão inadequada de assistência e de serviços públicos básicos às populações pobres em expansão nas aglomerações urbanas." 34

Mesmo os investimentos públicos tendem a reforçar o padrão segregacionista de produção do espaço. Conforme aponta Maricato: "A natureza e a localização dos investimentos, governamentais em primeiro plano e privados em segundo, regula quem e quantos terão o direito à cidade. Ela influi ainda nas características da segregação territorial e na qualidade de vida de cada bairro." Esse padrão de qualidade depende, prioritariamente, de quem controla os benefícios resultantes dos investimentos públicos e a história de nossas cidades tem demonstrado até agora a soberania absoluta do mercado, confirmando o espaço urbano como uma instância da dominação econômica.

De fato, as áreas onde predomina a população de baixa renda nas cidades brasileiras caracterizam-se pela deficiência dos serviços urbanos básicos, precária situação sanitária e habitações inadequadas, na maioria das vezes em situação ilegal.

Pretendemos discutir aqui o processo de estruturação do espaço urbano que, ao gerar a segregação social, contribui para a degradação ambiental. Entendemos que a mediação entre estruturação do espaço e degradação ambiental passa pelos padrões segregacionistas de uso e ocupação do solo decorrentes do processo de produção da cidade. Passamos agora a praticar essa argumentação em uma análise concreta, mostrando a articulação dos conceitos apresentados em uma situação histórica específica.

\section{A estruturação do espaço intra-urbano $35^{35}$ de curitiba}

Até 1900 , a ocupação do solo da cidade de Curitiba ocorreu de modo extensivo e com baixa densidade. Os assentamentos localizavam-se em sua maioria na área central, com algumas colônias hortigranjeiras espalhadas nos

32 HERCULANO, S. C. Do desenvolvimento (in)suportável à sociedade feliz. In: GOLDEMBERG, M. (Org.). Ecologia, ciência e política: participação social, interesses em jogo e luta de idéias no movimento ecológico. Rio de Janeiro: Revan, 1992. p. 28.

33 Ibid., p. 27.

34 MUELLER, C. C. Problemas ambientais de um estilo de desenvolvimento: a degradação da pobreza no Brasil. Revista Ambiente \& Sociedade, Campinas, ano 1, n. 1, p. $82,2 .^{\circ}$ sem. 1997.

35 Adotamos aqui a diferenciação apresentada por Villaça (1998), com respeito às expressões estrutura urbana e estrutura intra-urbana. O autor coloca que o termo estrutura urbana faz referência não somente ao espaço da cidade, mas também às componentes regionais desse espaço, enquanto que estrutura intra-urbana refere-se apenas às componentes do espaço interno de uma cidade. 
arredores do município. Verificava-se pequeno adensamento ao longo das vias de ligação entre as colônias e a área central.

Até o início do século XX, o crescimento ocorreu de forma claramente radiocêntrica, tendência que se alterou a partir de 1950, quando a ocupação passou a se dar predominantemente na direção nordeste-sudoeste.

Entre as décadas de 60 e 70 essa tendência persistiu, com uma extensa ocupação a nordeste e grandes loteamentos na região sul.

A década seguinte (período de 1980 a 1990) se caracterizou por uma grande expansão da malha urbana. Reforçando a tendência de ocupação radiocêntrica, o crescimento populacional concentrou-se nos bairros periféricos, especialmente ocupados por conjuntos habitacionais para população de baixa renda.

Nos últimos dez anos a cidade vem se expandindo na direção oeste e sul. Nas demais direções, a mancha urbana ultrapassou os limites municipais, reforçando o processo de conurbação que caracteriza a Região Metropolitana de Curitiba.

\section{FIGURA 1 - EIXOS ESTRUTURAIS DE CURITIBA}

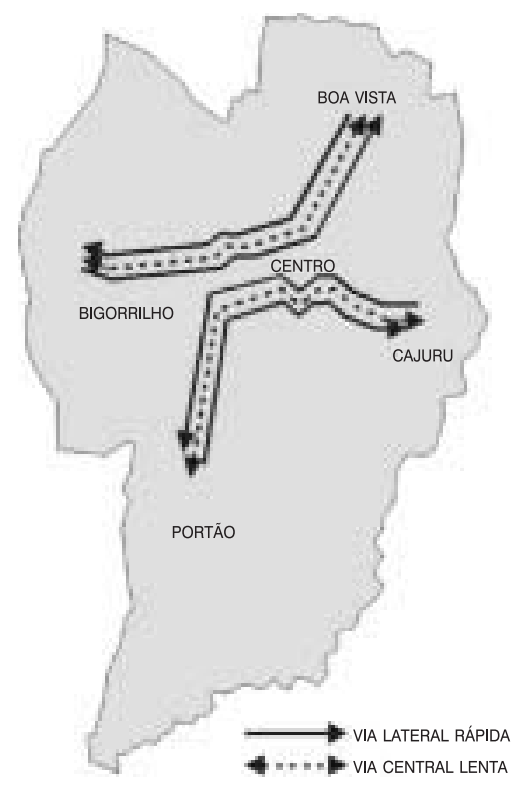

FONTE: SCHIMD, 1988.
O Plano Diretor de Curitiba, aprovado em 1966, propunha a consolidação do crescimento da cidade no sentido nordeste-sudoeste, o que foi feito com a implantação de eixos viários, denominados vias estruturais, que apresentavam a dupla função de catalizadores de atividades e eixo viário de circulação. Para conciliar essas funções foi concebido um sistema trinário, composto de três vias paralelas: uma via central, com canaletas para o transporte coletivo e pistas de tráfego lento, e duas vias rápidas, laterais a essa via central, de mão única com sentidos contrários.

A partir da implantação do sistema trinário, o crescimento da cidade passou a ser definido pelo tripé USO DO SOLO - CIRCULAÇÃO - TRANSPORTE (figura 1), com a expansão da cidade ocorrendo ao longo dos eixos estruturais, tangentes à área central. Na verdade,

Em decorrência de sua função relativamente ao contexto global da cidade, como linearizadores do centro tradicional, (os eixos estruturais) implicaram em um completo redirecionamento do uso do solo, ou seja, todos os demais setores não estruturais terão(tiveram) o seu adensamento limitado, proporcionando-se os maiores estímulos ao adensamento nos setores estruturais. A lei de zoneamento urbano passa a ser orientada segundo esse critério. ${ }^{36}$

A implantação dos eixos estruturais interferiu fortemente na dinâmica de ocupação do espaço da cidade. Foi induzido um alto adensamento ao longo dos eixos, mediante oferta de novas alternativas de habitação, comércio de médio porte e prestação de serviços básicos e foram implementadas obras físicas de grande porte, para garantir à população infra-estrutura e transporte. Essas obras, associadas a padrões específicos de ocupação do solo, constituem ainda hoje os elementos definidores da estrutura intraurbana de Curitiba.

\section{A estruturação socioespacial}

O processo de ocupação do espaço de Curitiba revela a articulação entre estrutura social e localização espacial.

36 INSTITUTO DE PESQUISA E PLANEJAMENTO URBANO DE CURITIBA. Projeto integrado de circulação e transporte. Curitiba: IPPUC, 1975. cf. PEREIRA, G. Planejamento urbano e qualidade de vida: reflexão a partir de um bairro de Curitiba. Rio de Janeiro, 1993. Dissertação (Mestrado) - IPPUR, UFRJ. p. 35. 
PEREIRA, G. A natureza (dos) nos fatos urbanos: produção do espaço e degradação ambiental

\section{FIGURA 2 - TAXA DE CRESCIMENTO POPULACIONAL 91/96}

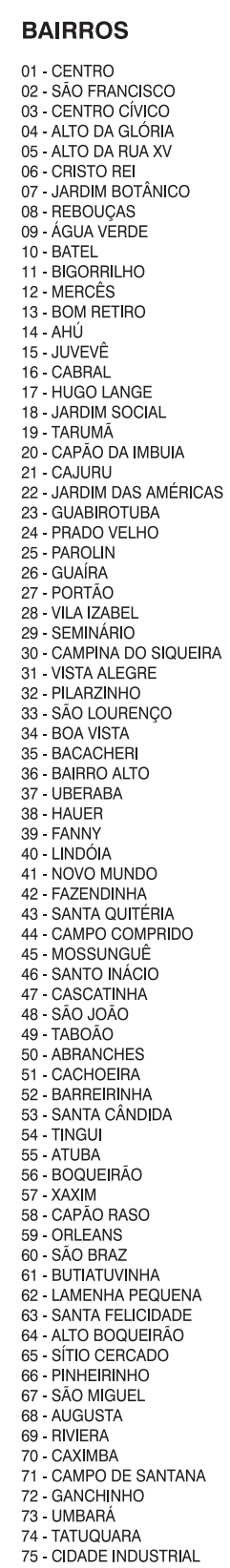

75 - CIDADE INDUSTRIAL

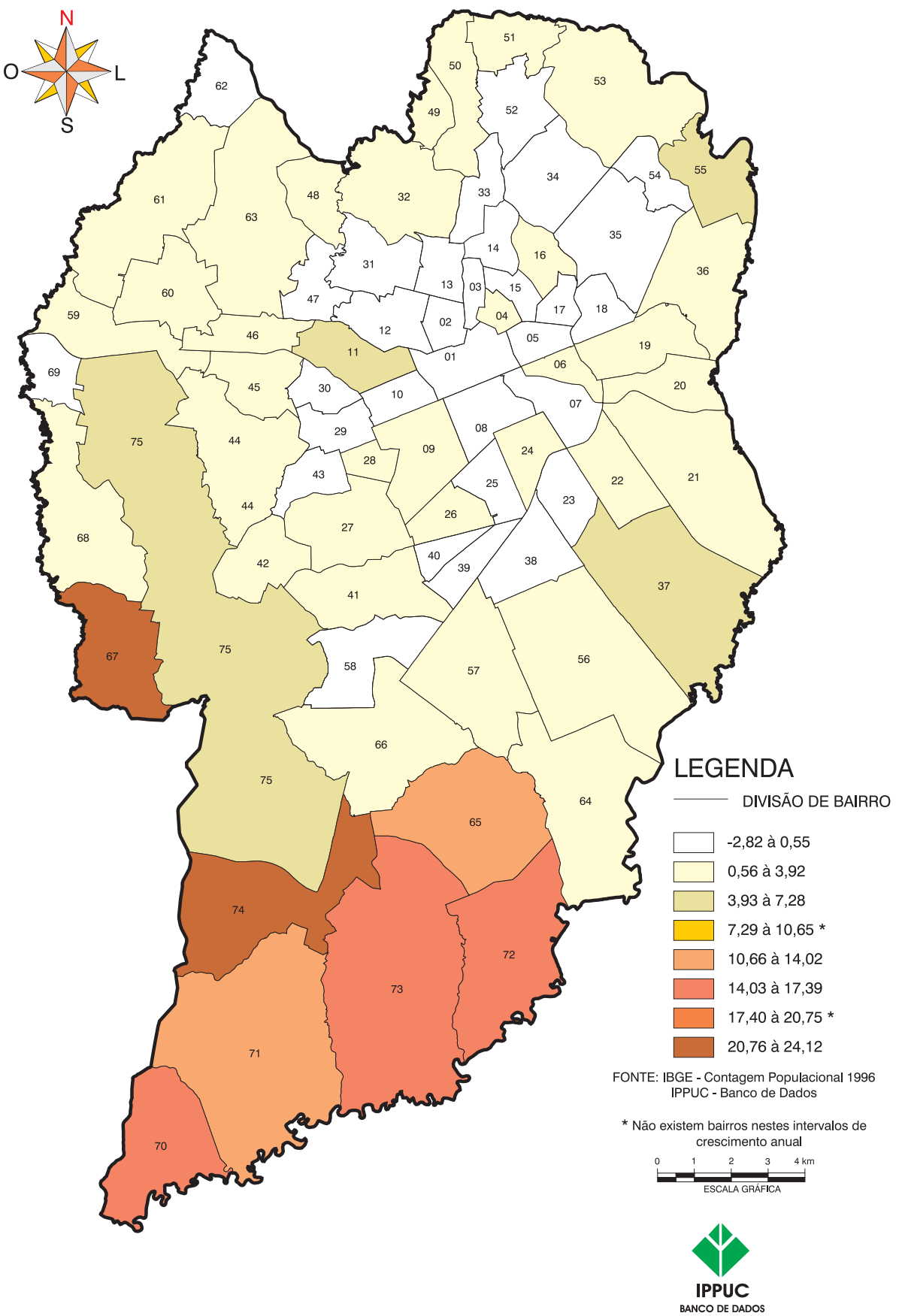

Desenvolvimento e Meio Ambiente, n. 3, p. 33-51, jan./jun. 2001. Editora da UFPR 
PEREIRA, G. A natureza (dos) nos fatos urbanos: produção do espaço e degradação ambiental

\section{FIGURA 3 - MAPA DA CONDIÇÃO DE POBREZA}

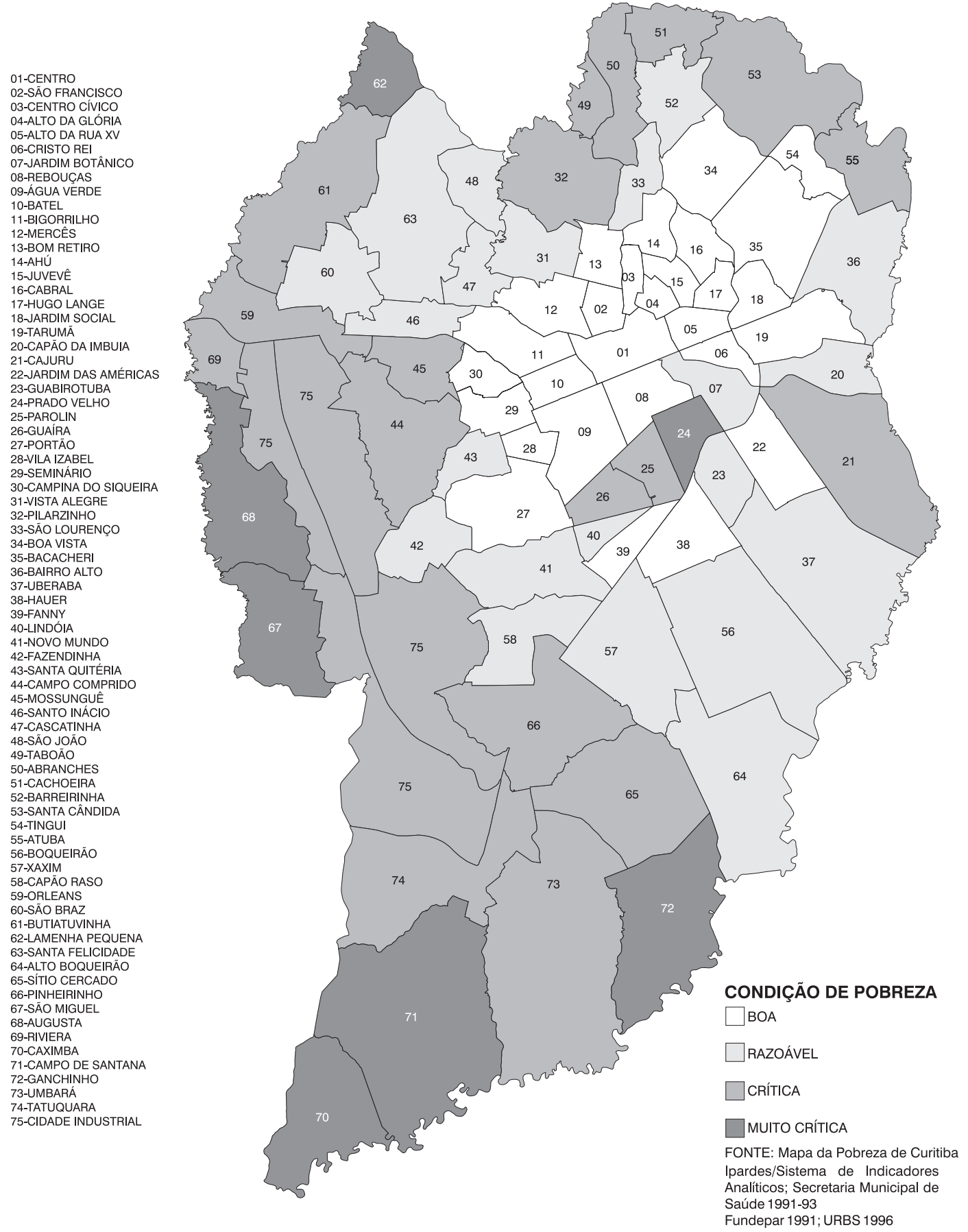


A análise dos dados referentes ao crescimento populacional nas últimas décadas indica que no período 1970/80 os bairros que mais cresceram foram Alto Boqueirão e Sítio Cercado, na região sudeste da cidade, seguidos por uma série de bairros localizados radialmente ao centro, confirmando a tendência radiocêntrica de ocupação do espaço e contrapondo-se ao objetivo da implantação dos eixos estruturais que era induzir a ocupação linear e tangente ao centro.

No período seguinte, 1980-91, há um forte crescimento da região sul da cidade, especialmente nos bairros que na década anterior eram caracterizados como rurais. Esta direção de crescimento se mantém no período seguinte (1991-96), refletindo uma forte tendência de ocupação nessa direção.

Em termos de densidade demográfica verifica-se que, na década de 70, a cidade densificou-se na direção nordeste-sudoeste, acompanhando o desenho dos eixos viários estruturais, implantados nesse período. Essa situação repetiu-se na década seguinte, com uma concentração populacional ao longo dos eixos estruturais. A contagem populacional de 1996 indicou o adensamento dos bairros periféricos, especialmente Cidade Industrial, a oeste, e Bairro Alto, Cajuru e Capão da Imbuia, a leste.

Pode-se verificar, portanto, que nem sempre há correspondência entre maiores taxas de crescimento e maiores densidades, o que pode ser explicado pela tendência de expansão da cidade sobre áreas de uso rural, que apresentavam baixa densidade populacional. De qualquer maneira, a permanência das taxas de crescimento mais elevadas na região sul, no período de duas décadas, indica que esta é a direção de expansão urbana, mesmo que não seja aí onde se verifiquem de imediato as maiores densidades demográficas.

O documento Mapa da Pobreza de Curitiba, ${ }^{37}$ identifica as áreas de maior pobreza, cruzando informações referentes a condição do domicílio, saneamento básico, condi- ções sociais do morador e condição dos serviços de educação, saúde e transporte coletivo. ${ }^{38}$ De acordo com esse documento, Curitiba possui 45.160 domicílios com chefes de família com renda de até 1 salário mínimo. Neles residem 159.431 pessoas, ou seja, $12,26 \%$ da população total do município. Também segundo esse estudo, 62.140 domicílios, que abrigam 231.888 moradores, são considerados precários, seja pelas condições sociais dos moradores, seja pela deficiência em saneamento básico.

A análise dos indicadores confirma que os bairros em melhores condições estão localizados na porção central do município: Centro Cívico, Cabral, São Francisco, Batel, Alto da Glória, Centro, Jardim Social, Hugo Lange, Juvevê e Água Verde.

Os bairros com maior grau de carência localizam-se ao sul, oeste e no limite norte: Caximba, Ganchinho, São Miguel, Campo de Santana, Augusta, Lamenha Pequena, Tatuquara, Riviera e Mossunguê, na periferia do município, e Prado Velho, próximo ao centro, onde existe uma grande área de ocupação irregular.

Ao cruzarmos as informações referentes a crescimento populacional e condições sociais fica evidente: a) a existência de um vetor de expansão da ocupação no sentido sudoeste; b) a condução desse processo de expansão é feita pela população de baixa renda; c) predominam baixos padrões de condições sociais nesse processo de expansão; d) existem grandes diferenças intra-urbanas que indicam a desigualdade social da estruturação do espaço da cidade.

Tomando como referência o documento Mapa da Pobreza de Curitiba, ${ }^{39}$ a desigualdade das condições sociais dos bairros pode ser identificada pela comparação entre alguns indicadores: a proporção de domicílios sem canalização interna varia de $0,05 \%$, no bairro Bom Retiro, a $84,03 \%$, no São Miguel; a proporção de domicílios com instalação sanitária ligada à rede de esgotos varia de $0,14 \%$, no Ganchinho, a 97,29\%, no Água Verde; a proporção de chefes de domicílio com rendimento de até 1 salário míni-

37 UNIVERSIDADE FEDERAL DO PARANÁ/INSTITUTO PARANAENSE DE DESENVOLVIMENTO ECONÔMICO E SOCIAL/INSTITUTO DE PESQUISA E PLANEJAMENTO URBANO DE CURITIBA. Mapa da pobreza de Curitiba. Curitiba: UFPR, 1997.

38 Para a elaboração desse documento foram utilizados os resultados do Censo 91. Como o documento esclarece, "a defasagem em relação ao presente não invalida os resultados da análise, dado que as informações são tratadas de forma relativa (a partir de percentuais em relação ao total de domicílios ou da população) traçando um perfil do bairro perante os demais". Cf. op. cit., p. 2.

39 UNIVERSIDADE FEDERAL DO PARANÁ / INSTITUTO PARANAENSE DE DESENVOLVIMENTO ECONÔMICO E SOCIAL / INSTITUTO DE PESQUISA E PLANEJAMENTO URBANO DE CURITIBA, op. cit. 
PEREIRA, G. A natureza (dos) nos fatos urbanos: produção do espaço e degradação ambiental

mo varia de 3,71\%, no Jardim Social, a 59,32\%, no São Miguel; a proporção de chefes de família com grau de instrução até a $1^{\mathrm{a}}$ série do $1^{\circ}$ grau varia de $0,58 \%$, no Centro Cívico, a 43,39\%, no Caximba.

A leitura das informações acima evidencia a existência de segregação sócio-espacial em Curitiba; as áreas periféricas são ocupadas pela população com piores condições sociais e as localizações centrais são ocupadas pela população com melhores condições.

\section{Dinâmica imobiliária e estruturação urbana}

A análise da dinâmica do mercado de imóveis em Curitiba nos últimos dez $\operatorname{anos}^{40}$ (1991 a 1999) permite identificar os bairros onde foi construído o maior número de edificações, indicando as áreas de atividade imobiliária formal mais intensa. ${ }^{41}$ Nesse caso, podemos verificar que há predomínio de unidades concluídas na região oeste da

TABELA 1 - NÚMERO DE UNIDADES RESIDENCIAIS CONCLUÍDAS - CURITIBA - 1991/1999

\begin{tabular}{c|c|c|c|c|c|c|c|c|c}
\hline \multicolumn{7}{c}{ NÚMERO DE UNIDADES RESIDENCIAIS CONSTRUÍDAS } \\
\hline & $\mathbf{1 9 9 1}$ & $\mathbf{1 9 9 2}$ & $\mathbf{1 9 9 3}$ & $\mathbf{1 9 9 4}$ & $\mathbf{1 9 9 5}$ & $\mathbf{1 9 9 6}$ & $\mathbf{1 9 9 7}$ & $\mathbf{1 9 9 8}$ & $\mathbf{1 9 9 9}$ \\
\hline $\begin{array}{c}\text { Até } 2 \\
\text { pavtos }\end{array}$ & 2272 & 2587 & 3580 & 3079 & 2697 & 3346 & 4382 & 4472 & 4684 \\
\hline 3 a 6 pavtos & 2607 & 1900 & 1864 & 1964 & 804 & 1901 & 2571 & 4542 & 3159 \\
\hline + 6 pavtos & 1293 & 1206 & 1786 & 1923 & 1718 & 1530 & 2150 & 2413 & 1682 \\
\hline TOTAL & $\mathbf{6 1 7 2}$ & $\mathbf{5 6 9 3}$ & $\mathbf{7 2 3 2}$ & $\mathbf{6 9 6 6}$ & $\mathbf{5 2 1 9}$ & $\mathbf{6 7 7 7}$ & $\mathbf{9 1 0 3}$ & $\mathbf{1 1 4 2 7}$ & $\mathbf{9 5 2 5}$ \\
\hline
\end{tabular}

FONTE: ADEMI - Perfil Imobiliário de uma Metrópole (1987-2000), 2001.

TABELA 2 - NÚMERO DE UNIDADES RESIDENCIAIS CONCLUÍDAS - CURITIBA - 1991/1999

\begin{tabular}{c|l|l|l|l|l|l|l|l|l}
\hline \multirow{2}{*}{$\begin{array}{c}\text { ÁREA } \\
\mathrm{m} 2\end{array}$} & \multicolumn{6}{c}{ NÚMERO UNIDADES RESIDENCIAIS CONCLUÍDAS } \\
\cline { 2 - 10 } & $\mathbf{1 9 9 1}$ & $\mathbf{1 9 9 2}$ & $\mathbf{1 9 9 3}$ & $\mathbf{1 9 9 4}$ & $\mathbf{1 9 9 5}$ & $\mathbf{1 9 9 6}$ & $\mathbf{1 9 9 7}$ & $\mathbf{1 9 9 8}$ & $\mathbf{1 9 9 9}$ \\
\hline $000-110$ & 4038 & 3761 & 5460 & 4465 & 2788 & 3346 & 4382 & 4472 & 4684 \\
\hline $111-250$ & 1707 & 1421 & 1468 & 1920 & 1994 & 1901 & 2571 & 4542 & 3159 \\
\hline mais 250 & 427 & 511 & 302 & 581 & 437 & 1530 & 2150 & 2413 & 1682 \\
\hline TOTAL & $\mathbf{6 1 7 2}$ & $\mathbf{5 6 9 3}$ & $\mathbf{7 2 3 0}$ & $\mathbf{6 9 6 6}$ & $\mathbf{5 2 1 9}$ & $\mathbf{6 7 7 7}$ & $\mathbf{9 1 0 3}$ & $\mathbf{1 1 4 2 7}$ & $\mathbf{9 5 2 5}$ \\
\hline
\end{tabular}

FONTE: ADEMI - Perfil Imobiliário de uma Metrópole (1987-2000), 2001.

cidade, confirmando a tendência de crescimento apontada anteriormente. Além disso, observando as tabelas 1 e 2 podemos verificar que dentro do número total de unidades residenciais concluídas nesse período predominam aquelas com até dois pavimentos e com área de até $110 \mathrm{~m}^{2}$, o que, segundo a Ademi,${ }^{42}$ caracteriza, em termos de mercado imobiliário, a edificação destinada à população de baixa renda.

As informações da Ademi tratam da produção formal de unidades residenciais, uma vez que são trabalhadas

40 Os dados que servem como referência para análise foram obtidos nos boletins anuais (Perfil Imobiliário de uma Metrópole) da Ademi (Associação de Dirigentes de Empresas do Mercado Imobiliário do Paraná). Foram analisados os boletins de 1987 a 2000, mas somente a partir de 1992 o boletim lança informações por bairro. O boletim é editado anualmente, no segundo semestre, contendo informações do primeiro semestre do ano da edição e do segundo semestre, do ano anterior. 41 Foram considerados os imóveis concluídos, e não os lançamentos, uma vez que o objetivo é avaliar a ocupação real e não somente as tendências de ocupação futura.

42 A Ademi adota a seguinte classificação das edificações: até $110 \mathrm{~m}^{2}$ destinadas à baixa renda; de $111 \mathrm{~m}^{2}$ a $250 \mathrm{~m}^{2}$ à classe média e edificações com mais de $251 \mathrm{~m}^{2}$ são destinadas à população de alta renda. 
informações do Cadastro da Prefeitura Municipal, referentes aos alvarás expedidos, de licença ou de conclusão de obra. ${ }^{43}$ Contrapondo-se a essa produção há, entretanto, a produção informal de residências, que ocorre de forma ilegal, seja porque a construção não é registrada ou porque o terreno não têm propriedade regularizada (invasões).

Sem contarmos com informações precisas sobre a primeira situação (edificações não registradas) consideramos os domicílios irregulares existentes na cidade. Nesse caso, levantamento recente da administração municipal ${ }^{44}$ contabiliza 57.333 domicílios irregulares, o que corresponde a aproximadamente 200.000 pessoas. Isto significa que mais de $10 \%$ da população de Curitiba não tem acesso ao mercado formal de terras.

A observação da dinâmica dos valores imobiliários de 1985 e 1997 indica que não houve uma alteração substancial da distribuição espacial das áreas mais valorizadas de Curitiba. Mantendo a forma radiocêntrica, os imóveis vão decrescendo em valor à medida que se afastam do centro da cidade. Há uma tendência de expansão de áreas mais valorizadas na direção leste, quase alcançando o limite do Município, a qual se opõe à tendência predominante de expansão da cidade, que está ao sul. Isso significa que o processo de expansão ocorre sobre as áreas de menor valor e é conduzido pela população de menor renda, que só têm acesso aos imóveis dessa categoria.

Por outro lado, ao cruzarmos a situação dos valores imobiliários, ocupações irregulares e taxa de crescimento populacional de Curitiba podemos concluir que a expansão da cidade (predominantemente em direção ao sul), além de ocorrer nas terras de menor valor e ser comandada pela população de baixa renda, ocorre de forma irregular, ou ilegal.

A análise dos dados disponíveis para a cidade indica uma polarização nordeste/sudoeste, em relação aos padrões de ocupação do solo. Na região norte/nordeste estão concentrados: população de maior renda, melhores condições sociais e maiores valores imobiliários. A região sul/oeste caracteriza-se pelo oposto: menor renda, pior condição so- cial, menores valores imobiliários e, significativamente, maiores taxas de crescimento populacional e maior número de ocupações irregulares.

Considerando essa polarização de condições sociais, interessa-nos verificar a degradação ambiental na cidade, analisando a relação entre estruturação do espaço, segregação socioespacial e degradação ambiental.

\section{Saneamento básico e degradação ambiental em Curitiba}

De acordo com Mueller, ${ }^{45}$ os problemas ambientais das cidades brasileiras podem ser classificados em dois tipos: a degradação resultante dos padrões de consumo da parcela da população com renda média e alta e os problemas ambientais resultantes dos padrões de vida da população de baixa renda.

Vamos priorizar aqui o reconhecimento da degradação causada pela pobreza e que está associada à provisão inadequada dos serviços básicos de infra-estrutura. Concordamos com Mueller que "a deficiência mais grave dos assentamentos urbanos de baixa renda é a que resulta da falta de condições inadequadas de captação, canalização e disposição de dejetos humanos." ${ }^{46}$

O documento Relatório Ambiental da Região Metropolitana de Curitiba, ${ }^{47}$ afirma que a precariedade do esgotamento sanitário é a questão mais grave do quadro ambiental da Região Metropolitana de Curitiba, e isso não se restringe às áreas de ocupação da população de baixa renda.

Embora os investimentos nesse serviço tenham aumentado significativamente nos últimos anos (vide tabela 3 ), cerca de $40 \%$ da população não tem acesso ao esgotamento sanitário, o que significa aproximadamente 170.000 domicílios.

Utilizando as informações do documento Mapa da Pobreza de Curitiba $^{48}$ constatamos que mais de $16 \%$ dos

\footnotetext{
43 A pesquisa apresentada nos boletins da Ademi utiliza dados referentes a unidades residenciais licenciadas, ou seja, que receberam o Alvará Classe A de Construção e unidades residenciais concluídas, que receberam o Certificado de Conclusão, ambos emitidos pela Prefeitura Municipal.

44 INSTITUTO DE PESQUISA E PLANEJAMENTO URBANO DE CURITIBA(IPPUC). Ocupações Irregulares. Curitiba 1999/2000. Curitiba: IPPUC, março, 2001. 45 MUELLER, op. cit.

46 MUELLER, op. cit., p. 86.

47 COORDENAÇÃO DA REGIÃO METROPOLITANA DE CURITIBA - Comec. Relatório Ambiental da Região Metropolitana de Curitiba. Curitiba: Comec, 1997.

48 Ipardes, op. cit.
} 
PEREIRA, G. A natureza (dos) nos fatos urbanos: produção do espaço e degradação ambiental

TABELA 3 - POPULAÇÃO ATENDIDA POR ESGOTO SANITÁRIO - CURITIBA - 1980/2000

\begin{tabular}{c|c|c|c|c|c}
\hline ANO & $\begin{array}{c}\text { POPULAÇÃO } \\
\text { URBANA }\end{array}$ & $\begin{array}{c}\text { CRESCIMENTO } \\
\text { GEOMÉTRICO ANUAL } \\
\text { DA POPULAÇÃO } \\
\%\end{array}$ & $\begin{array}{c}\text { POPULAÇÃO } \\
\text { ATENDIDA }\end{array}$ & $\begin{array}{c}\% \\
\text { ATENDIMENTO }\end{array}$ & $\begin{array}{c}\text { TAXA MÉDIA } \\
\text { CRESCIMENTO } \\
\text { GEOMÉTRICO ANUAL } \\
\text { DO ATENDIMENTO }\end{array}$ \\
\hline 1980 & 1.024 .975 & 5,34 & 413.103 & 40 & - \\
\hline 1992 & $1.315 .035^{1}$ & 2,29 & 640.817 & 48,73 & 3,73 \\
\hline 1996 & $1.476 .253^{2}$ & 2,38 & 756.875 & 51,27 & 4,25 \\
\hline 2000 & $1.586 .898^{3}$ & 1,82 & 976.101 & $61,51^{4}$ & 6,57 \\
\hline
\end{tabular}

FONTE: SANEPAR, 2000.

NOTAS: ${ }^{1}$ Censo Populacional 1991 - IBGE

${ }^{2}$ Contagem populacional 1996 - IBGE

${ }^{3}$ Resultado preliminar Censo 2000 - IBGE

${ }^{4} 19 \%$ do esgoto coletado em Curitiba não tem tratamento

bairros de Curitiba têm elevada proporção de domicílios em condição crítica ou muito crítica de saneamento básico. Em relação à ligação à rede de água, que é o serviço mais ofertado do saneamento, cerca de $80 \%$ dos domicílios dispõem do serviço. A proporção de domicílios com instalação sanitária ligada à rede de esgotos é inferior a $27,23 \%$ e a coleta de lixo atende a cerca de $87 \%$ dos domicílios.

Os bairros situados ao norte, sul e oeste da cidade apresentam maior precariedade de saneamento básico, confirmando a região central e leste como aquelas melhor servidas. Ao cruzarmos essas informações com os dados referentes à condição social do morador verificamos que são praticamente coincidentes as áreas consideradas críticas de acordo com esses dois indicadores: condição de saneamento básico e condição social do morador. Fica evidente, portanto, a relação que Mueller ${ }^{49}$ apontou entre pobreza e degradação ambiental gerada pela deficiência de serviços básicos.

A precariedade de saneamento básico, além de problemas de saúde pública, tem como conseqüência direta a degradação da qualidade hídrica. Entre as principais fontes de poluição da água superficial e subterrânea estão: lançamento de esgotos domésticos; lançamento de esgotos industriais; lançamento de águas pluviais, através de gale- rias; água de escoamento superficial, água de infiltração e lançamento direto de resíduos sólidos e outras impurezas. ${ }^{50}$

Em Curitiba, o único rio ainda utilizado para abastecimento de água é o Passaúna, limite oeste do Município, cuja bacia abrange também áreas dos municípios de Araucária, Campo Largo e Almirante Tamandaré. Os demais rios que percorrem a cidade estão totalmente comprometidos pela poluição.

Ao analisarmos o processo de estruturação de Curitiba, verificamos que o rio Passaúna corre sério risco de degradação, uma vez que na região sul e oeste da cidade encontram-se as piores condições sociais, associadas às maiores taxas de crescimento populacional e à concentração de ocupações irregulares. Ou seja, mantendo-se o padrão de estruturação urbana existentes, no qual se associa ocupação do território, disponibilidade de serviços e condições sociais, o último rio vivo da cidade tem um fim anunciado.

\section{Novas questões à guisa de conclusão}

Neste trabalho, procuramos discutir a degradação ambiental como resultado do processo de produção da cidade. Embora essa afirmação pareça óbvia, ela é a base

49 MUELLER, op. cit.

50 Os principais fatores de poluição hídrica estão indicados em MOTA, S. Urbanização e meio ambiente. Rio de Janeiro: ABES, 1999. 
PEREIRA, G. A natureza (dos) nos fatos urbanos: produção do espaço e degradação ambiental

\section{FIGURA 4 - BACIAS HIDROGRÁFICAS DE CURITIBA}

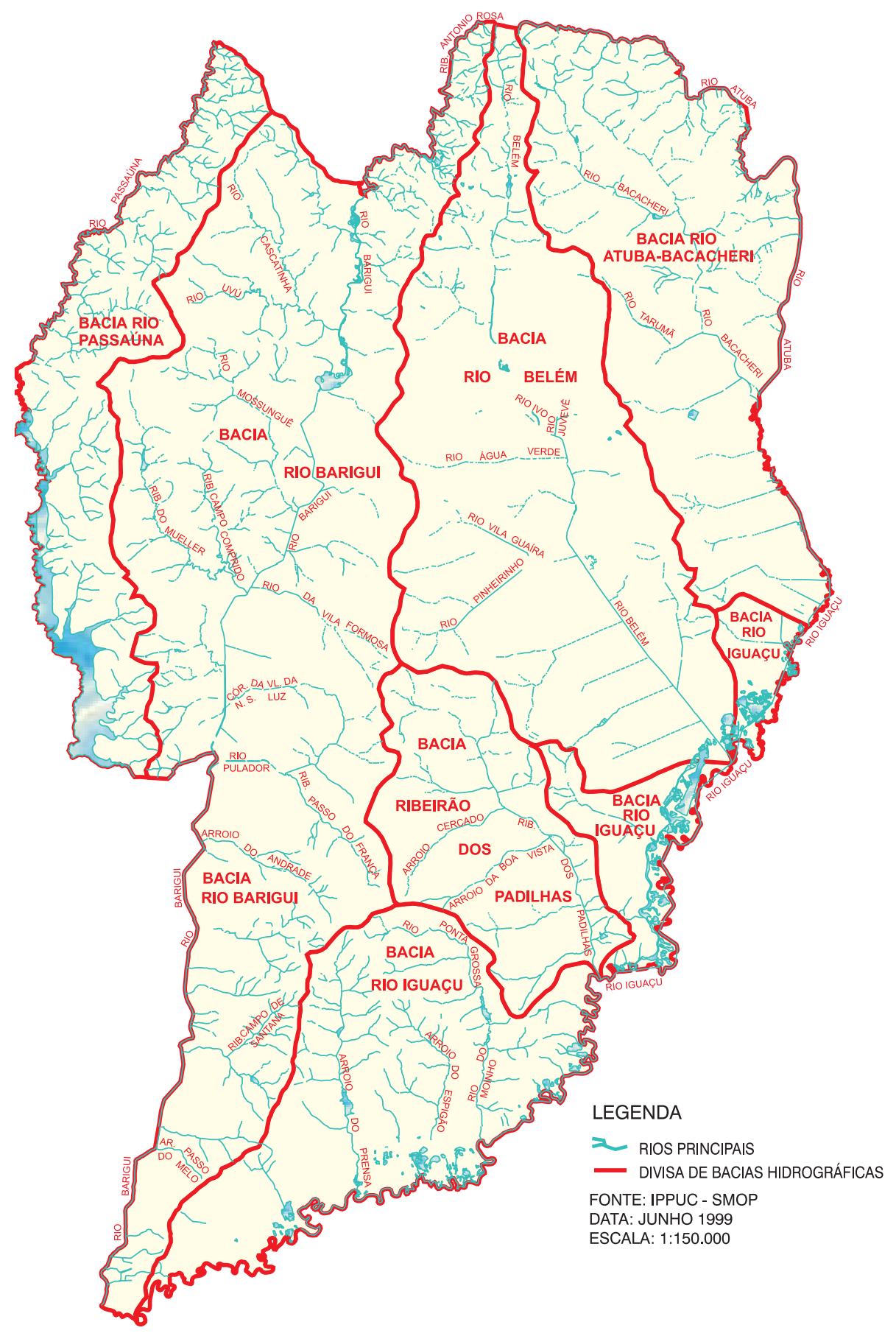


para a proposição de soluções. As propostas não podem centrar-se apenas no problema, ou seja, na degradação ambiental, mas nas causas que o criam, sua essência. A análise dos indicadores de degradação ambiental tem que ser feita de maneira não reducionista; é preciso compreender as contradições do processo de urbanização, identificando quem é beneficiado por esse processo e quem dela é excluído. Os problemas ambientais dizem respeito às formas pelas quais a sociedade se relaciona com a natureza no processo de produção do seu espaço de sobrevivência. Como coloca Rodrigues:

A problemática ambiental traz à tona que o ideário do desenvolvimento, mesmo o desenvolvimento sustentável, compreendido como a produção contínua de novas mercadorias, o progresso tido como o avanço científico tecnológico, é fundamentalmente problemático. (...) a questão ambiental tem de ser compreendida como produto das contradições do modo industrial de produzir mercadorias. ${ }^{51}$

O processo de produção da cidade produz ao mesmo tempo mercadorias-territórios desejáveis e indesejáveis. A mercadoria "solo" é desejável quando permite auferir valor na sua comercialização; o solo é mercadoria quando é "legal", ou passível de ser legalizado. A mercadoria indesejável, que não interessa ao mercado, é o terreno que não pode ser legalizado, geralmente por estar em área ambientalmente frágil. Quem tem renda suficiente, adquire a mercadoria legal, desejável: o solo bem localizado. Para quem não tem, resta a mercadoria indesejável; as piores localizações.

O processo de produção do espaço cria localizações e a qualidade de uma área é a medida indireta (oculta) da má qualidade de outras áreas da cidade. Mesmo a cidade legal só é legal em contraposição à ilegalidade de outras áreas. Nesse processo, é claro que os mais atingidos são aqueles que não têm renda para acessar às boas localizações.

Conforme coloca Maricato, "a produção e a apropriação do espaço urbano não só reflete as desigualdades e as contradições sociais, como também as reafirma e reproduz. (...) O ambiente construído não existe independentemente das relações sociais." 52 Não reconhecer isso nos leva à manutenção do padrão contraditório, desigual e predatório com que tem evoluído nossas cidades, cuja gestão tem se caracterizado, conforme resume Maricato, ${ }^{53}$ por: definição pelas megaempreiteiras quanto à prioridade de obras públicas; localização de investimentos obedecendo à lógica da extração da renda imobiliária; confirmação de espaços exclusivos e segregados e aplicação arbitrária da legislação, beneficiando parte da cidade.

É evidente que reverter essa situação não é uma tarefa simples, nem de curto prazo e nem exclusiva de um poder local, mas torna-se impositiva, caso se pretenda uma mudança nos padrões de qualidade do ambiente urbano.

A "crise" urbana, parece não ser uma crise, uma vez que seus sintomas vem se manifestando há alguns séculos. O que pode ser chamada de crítica é a degradação do ambiente urbano, cujos efeitos têm tido maiores repercussões neste último século. Mas, toda crise traz riscos e oportunidades; riscos de que a situação piore e oportunidades de grandes mudanças. Talvez essa seja a oportunidade para revisão dos parâmetros de crescimento das nossas cidades, de modo que deixe de ser considerado natural o que muito se repete. Uma releitura do processo de produção da cidade à luz da problemática socioambiental talvez possa responder aos desafios da transformação de nossas cidades em ambientes sustentáveis.

A cidade de Curitiba espelha a realidade que discutimos, demonstrando as contradições da produção do espaço que se baseia em um conceito de "progresso" urbano que contém em si mesmo sua negação: a qualidade de uma área é medida em contraposição à precariedade de outras.

Essa contradição da dinâmica urbana pode ser expressa em números: existem na cidade 57.333 domicílios em condição irregular, onde habitam cerca de 200.000 pessoas sem recursos para adquirir um terreno de forma legal. Demonstramos aqui a correlação entre moradia ilegal, segregação social e degradação ambiental. Nessa mesma cidade, a Prefeitura Municipal informa a

51 RODRIGUES, op. cit., p. 77.

52 MARICATO, E. As idéias fora do lugar e o lugar fora das idéias. In: ARANTES, O. et al. A cidade do pensamento único: desmanchando consensos. Petrópolis: Vozes, 2000. p. 170.

53 Id. 
PEREIRA, G. A natureza (dos) nos fatos urbanos: produção do espaço e degradação ambiental

Existência de pelo menos 42.046 terrenos baldios ou construções abandonadas, locais que têm atormentado a vida de muitos moradores por se transformarem em depósitos de lixo alternativos, viveiros de insetos e outros animais ou mocós. Desde janeiro a prefeitura acumula 2.565 registros de pessoas reclamando de problemas relacionados a esses imóveis." ${ }^{54}$

Como trabalhar com essa contradição resultante do processo de produção do espaço, fazendo com que a solução do segundo problema contribua para atenuar o primeiro? Como enfrentar essa situação, que se repete em várias cidades, de modo a tornar a prática urbanística uma "ação de resistência" à exclusão e à degradação?

Propostas alternativas para intervenções no urbano com o objetivo de mudar o padrão excludente de estruturação do espaço constituem-se em grande desafio. Conhecimento é o que não falta, recursos e instrumentos também; como diz Herrera, ${ }^{55}$ é a primeira vez na história da humanidade que esta possui o conhecimento necessário para resolver todos os problemas ligados à base material da vida.

Entretanto, a correlação entre segregação sócioespacial e degradação ambiental, de tanto repetir-se, passou a ser "natural" ao espaço urbano. Os problemas ambientais são tratados como produtos indesejáveis do progresso, "des- vios de meta", e não como resultado material da dinâmica própria da produção da cidade. Para reverter essa situação é necessário enfrentar o desafio de propor alternativas viáveis para a realização de ajustes e correções ao processo de produção do espaço urbano. E para isso, o texto de Bertold Brecht nos serve como alerta: ${ }^{56}$

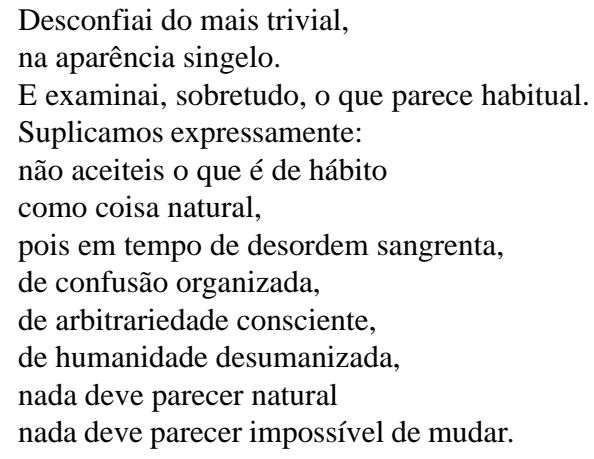

Enfim, para esse tema, não existem conclusões. O que aqui apresentamos pretende ser apenas um ponto de partida para novos questionamentos; para a formulação de novas e promissoras alternativas de melhoria da qualidade de vida em nossas cidades.

\section{REFERÊNCIAS}

ASSOCIAÇÃO DOS DIRIGENTES DE EMPRESAS DO MERCADO IMOBILIÁRIO DO PARANÁ - ADEMI. Perfil imobiliário de uma metrópole. Curitiba: ADEMI. Boletins 1989/2000.

CARLOS, A. F. A (re) produção do espaço urbano. São Paulo: Universidade de São Paulo, 1994.

CASTELLS, M. A questão urbana. Rio de Janeiro: Paz e Terra, 1983.

1999.
CENECORTA, A.; SMOLKA, M. O paradoxo da regularização fundiária: acesso à terra servida e pobreza urbana no México. Cadernos IPPUR, Rio de Janeiro, ano 14, n. 1, jan.jul. 2000.

COORDENAÇÃO DA REGIÃO METROPOLITANA DE CURITIBA - Comec. Relatório Ambiental da Região Metropolitana de Curitiba. Curitiba: Comec, 1997.

GOTTDIENER, M. A produção social do espaço urbano. São Paulo: Edusp, 1997.

54 GAZETA DO POVO. Curitiba, 23 mar. 2001

55 HERRERA, A. A grande jornada - a crise nuclear e o destino biológico do homem. São Paulo: Paz e Terra, 1982. p. 83.

56 BRECHT, B. Antologia Poética. Rio de Janeiro: Elo, 1982. p. 45. 
HARVEY, D. A justiça social e a cidade. São Paulo: Hucitec, 1980.

. A condição pós-moderna. Rio de Janeiro: Paz e Terra, 1999.

HERCULANO, S. C. Do desenvolvimento (in)suportável à sociedade feliz. In: GOLDEMBERG, M.(Org.). Ecologia, ciência e política: participação social, interesses em jogo e luta de idéias no movimento ecológico. Rio de Janeiro: Revan, 1992.

HERRERA, A. A grande jornada - a crise nuclear e o destino biológico do homem. São Paulo: Paz e Terra, 1982.

INSTITUTO DE PESQUISA E PLANEJAMENTO URBANO DE CURITIBA. Projeto Integrado de Circulação e Transporte. Curitiba: IPPUC, 1975.

Ocupações irregulares. Curitiba 1999/2000. Curitiba: IPPUC, mar., 2001.

GAZETA DO POVO. Curitiba, 23 mar. 2001.

LEFEBVRE, H. La revolución urbana. Madrid: Alianza Editorial, 1983. 2000.

The production of space. Massachusetts: Blackwell,

MARICATO, E. Metrópole na periferia do capitalismo; ilegalidade, desigualdade e violência. São Paulo: Hucitec, 1996.

. As idéias fora do lugar e o lugar fora das idéias. In: ARANTES, O. et al. A cidade do pensamento único: desmanchando consensos. Petrópolis: Vozes, 2000.

MOTA, S. Urbanização e meio ambiente. Rio de Janeiro: ABES, 1999.

MUELLER, C. C. Problemas ambientais de um estilo de desenvolvimento: a degradação da pobreza no Brasil. Revista Ambiente \& Sociedade, Campinas, ano 1, n. 1, 2. sem. 1997.
PEREIRA, G. Planejamento urbano e qualidade de vida: reflexão a partir de um bairro de Curitiba. Rio de Janeiro, 1993. Dissertação (Mestrado). IPPUR-Universidade Federal do Rio de Janeiro.

QUEIROZ RIBEIRO, L. C. Notas sobre a renda da terra urbana. Cadernos IPPUR/UFRJ, Rio de Janeiro, jan./abr., n. 1, 1986.

RODRIGUES, A. M. Produção e consumo do e no espaço: problemática ambiental urbana. São Paulo: Hucitec, 1998.

ROLNIK, R. Cidades sustentáveis: memória do encontro preparatório. In: Conferência sustentabilidade e gestão urbana, 1997, São Paulo. Anais... São Paulo: Secretaria do Meio Ambiente, set. 1997. p. 20.

SANTOS, M. A urbanização brasileira. São Paulo: Hucitec, 1994.

SANTOS, B. S. Notas sobre a história jurídico social de Pasárgada. In: SOUZA JUNIOR, J. G. (Org.). Introdução crítica ao direito. Brasília: Universidade de Brasília, 1993.

SINGER, P. O uso do solo na economia capitalista. In: MARICATO, E. (Org.). A produção capitalista da casa (e da cidade). São Paulo: Alfa-Omega, 1979.

SMITH, N. O desenvolvimento desigual. São Paulo: Bertrand Brasil, 1988.

UNIVERSIDADE FEDERAL DO PARANÁ/INSTITUTO PARANAENSE DE DESENVOLVIMENTO ECONÔMICO E SOCIAL/INSTITUTO DE PESQUISA E PLANEJAMENTO URBANO DE CURITIBA. Mapa da pobreza de Curitiba. Curitiba: UNIVERSIDADE FEDERAL DO PARANÁ, 1997.

VILLAÇA, F. Espaço intra-urbano no Brasil. In: GOLDEMBERG, M.(Org.). Ecologia, ciência e política: participação social, interesses em jogo e luta de idéias no movimento ecológico. Rio de Janeiro: Revan, 1992. 